\title{
Meteorological and hydrological variables on occurrence of riverbank erosion along Lower São Francisco River ${ }^{1}$
}

\author{
Igor P. da Rocha ${ }^{2}$, Francisco S. R. Holanda ${ }^{3}$, Renisson N. Araújo Filho ${ }^{4}$, \\ Ana P. B. Casado ${ }^{5}$ \& Arilmara A. Bandeira ${ }^{6}$
}

\begin{abstract}
The objectives of this paper were to analyze the seasonal distributions of climatic and hydrological variables along the Lower São Francisco River, Northeastern Brazil, between the States of Sergipe and Alagoas, and further, to verify their relationships with the erosion of the right margin in Sergipe State. The investigated area comprises the sedimentary portions of the Lower São Francisco River, located at the CotinguibaPindoba Irrigated Perimeter. Historical records of variables such as rainfall, river streamflow velocity, river discharge, wind velocity and the predominant direction were collected from a climatological station as well as rain and streamflow gauges located in the municipality of Propriá. The rainfall that occurs in the region is considered non-erosive, $96.2 \%$ of the rain had intensity less than $25.0 \mathrm{~mm} \mathrm{~h}^{-1}$. The evolution of erosion is explained by the increase in the outflow in February that peaked at $9,894.50 \mathrm{~m}^{3} \mathrm{~s}^{-1}$ and led to increases in the flow velocity. The rainfall regime interacts with the wind that blows predominantly from the eastern direction during the dry season and from the southeastern direction during the rainy season with maximum velocities of 5.5 and $8.0 \mathrm{~m} \mathrm{~s}^{-1}$, respectively.
\end{abstract}

Key words: river discharge, wind, rainfall, water resources

\section{Variáveis meteorológicas e hidrológicas sobre ocorrência de erosão no Baixo São Francisco}

\begin{abstract}
RESUMO
O objetivo deste trabalho foi analisar a distribuição sazonal de variáveis climáticas e hidrológicas ao longo do baixo curso do rio São Francisco, nordeste do Brasil, entre os estados de Sergipe e Alagoas e ainda verificar, também, suas relações com a erosão da margem direita no Estado de Sergipe. A área investigada compreende as porções sedimentares do Baixo São Francisco localizada no Perímetro Irrigado CotinguibaPindoba. Foram coletados os registros históricos de variáveis como a precipitação, a velocidade do fluxo do rio, vazão do rio, velocidade do vento e da direção predominante de uma estação climatológica, bem como chuva e medidores de vazão localizados no Município de Propriá. A precipitação que ocorre na região é considerada não-erosiva, $96,2 \%$ das chuvas tiveram intensidade menor que 25,0 $\mathrm{mm} \mathrm{h}^{-1}$. A evolução da erosão é explicada pelo aumento do fluxo em fevereiro que atingiu um máximo de 9894.50 $\mathrm{m}^{3} \mathrm{~s}^{-1}$ e levou a um aumento na velocidade do fluxo. O regime de chuvas interage com o vento, que sopra predominantemente na direção do leste durante a estação seca e da direção sudeste durante a estação chuvosa, com velocidades máximas de 5.5 e $8.0 \mathrm{~m} \mathrm{~s}^{-1}$, respectivamente.
\end{abstract}

Key words: vazão do rio, vento, chuva, recursos hídricos

\footnotetext{
1 Parte da Dissertação de Mestrado do primeiro autor apresentada ao Programa de Pós-Graduação em Agroecossistemas da UFS, com bolsa da CAPES ${ }^{2}$ DTR/UFRPE. R. Dom Manoel de Medeiros, s/n, Dois Irmãos, CEP 52171-900, Recife, PE. Fone: (81) 3320-6279. E-mail: rochaigor@hotmail.com ${ }^{3}$ LABES/UFS. Av. Mal. Rondon, s/n, Jardim Rosa Elze, CEP 49100-000, São Cristóvão, SE. E-mail: fholanda@infonet.com.br ${ }^{4}$ DEPA/UFRPE. R. Dom Manoel de Medeiros, s/n, Dois Irmãos, CEP 52171-900, Recife, PE. E-mail: nepoaraujo@hotmail.com

${ }^{5}$ IFS Campus Lagarto. Rodovia Lourival Batista s/n, Povoado Carro Quebrado, CEP 49400-000, Lagarto, SE. E-mail: apb_casado@hotmail.com ${ }^{6}$ IFS Campus Estância. Praça Jackson de Figueiredo, 49, Centro, CEP 49200-000, Estância, SE. E-mail: arilmara@ig.com.br
} 


\section{INTRODUCTION}

Riverbank erosion processes have commly been linked solely to water flow velocity (Fernandez \& Souza Filho, 1995), even though it is also well understood that other variables influence the erosion process too. In natural river channels, the factors that most directly affect the degree of bank stability, rate of advance, and bank erosion duration are the hydrodynamic characteristics of the flow near the slope, channel geometry, and the waves caused by wind and climatic and biological factors (Thorne \& Tovey, 1981; Simons \& Li, 1982). Moreover, although riverbank erosion in river channels is fundamentally a natural phenomenon, it is enhanced by anthropogenic activities that cause fluvial alterations that are directly transmitted along the streams (Pets, 1980; Shields Júnior et al., 2000; Brandt, 2000; Bhattacharyya, 2011). For example, along the São Francisco River, dam operations for energy generation involve the regularization of the river's discharges downstream of these structures (Graf, 2006; Manyari \& Carvalho Júnior, 2007; Coelho, 2008). According to Casado et al. (2002), this causes the water depth to remain at the same level for long periods since the force of the current has increased effects on the bank at that level and promotes the removal of soil particles. Holanda et al. (2007) explains that riverbank erosion along the lower course of the São Francisco River occurs primarily under normal day-to-day conditions even without destructive floods or other weather events; further, the author concludes that it is possible to observe the magnitude of the erosion process and retreat of the bank within a few days itself.

Coops et al. (1996) compared the effects of waves on artificial streams in the case of treatments with and without the protective vegetation and concluded that the erosion values for the unprotected banks were higher. Similarly Holanda et al. (2008) conducted studies along the Lower São Francisco River and attributed the changes in the cross-sections mainly to the actions of the shock waves at the base of the riverbank slopes.

When the wind direction coincides with the direction of the current, erosion processes occur with greater magnitudes due to increased formation of waves (Brighetti \& Martins, 2001; Ellis et al., 2002; Hughes et al., 2007), an important factor in the formation of waves and increases their shock power, thereby leading to progressive undercutting of the riverbanks and consequent landslides of the upper parts. Nanson et al. (1994) and Houser (2010) concluded that the waves caused by navigation also influence the occurrences of riverbank erosion, and that the origin mechanisms of this type of wave are different from the waves generated by winds and possesses less disruption potential than natural waves.

Christofoletti (1999) states that the main factors that contribute to the erosion, transport, and sedimentation processes in rivers are the current velocity; the physical characteristics of the sediments, specifically the size, density, and shape; the existence of accidents or obstacles in the bed; and the variations in river discharges, which, in turn, may also be related to climatic variations. The current velocity is considered a key factor for the erosion development along streams, because, in general, its increase is proportional to the volume of the eroded soil (Hooke, 1979), especially when the bank comprises non- cohesive soils (Rocha et al., 1999; Posner \& Duan, 2011). The river channel morphology is another important variable that reflects the adjustment of the river to the material excavation since it is a result of the action exerted by the flow on the material components of the bed and banks (Christofoletti, 1981). In addition, the distance between the channel and bank is a factor that influences the destabilization process of bank slopes (Michalková et al., 2011). The criteria established by Rosgen (1994) to classify rivers in terms of their morphological and hydraulic characteristics are channel form, velocity, and stream discharge; this clearly demonstrates the importance of these variables in the geomorphological processes of rivers.

The discharge of the main stream, especially in the lower courses, reflects the sum of the discharges of the upstream tributaries and is primarily influenced by the rainfall that occurs at the headwaters of the basin (Tucci, 2000); further, it has a close relationship with the current velocity. According to Takken et al. (1998), the increase in discharge reflects the increase in the river flow velocity, and this explains the recording of increased erosion rates during the flooding period in the rainy season when the river discharges are higher than during other periods.

The objectives of this paper were to analyze the seasonal distributions of climatic and hydrological variables along the Lower São Francisco River, northeastern Brazil, between the states of Sergipe and Alagoas, and further, it was verified their relationships with the erosion of the right margin in Sergipe.

\section{Material And Methods}

The investigated area is located along the sedimentary section of the Lower São Francisco river basin-along the CotinguibaPindoba Irrigated Perimeter - in the Propriá municipality, Sergipe state, northeastern Brazil (Figure 1). Further, the climate of the sedimentary section of the Lower São Francisco River has been classified by the Köppen classification system as Type Am (Megathermic humid and subhumid). The annual mean temperature is $25^{\circ} \mathrm{C}$ with December being the warmest month $\left(26-27{ }^{\circ} \mathrm{C}\right.$ ) and June the coldest month (around $23{ }^{\circ} \mathrm{C}$ ).

To investigate this specific river stretch, meteorological data were collected from the closest meteorological stations having

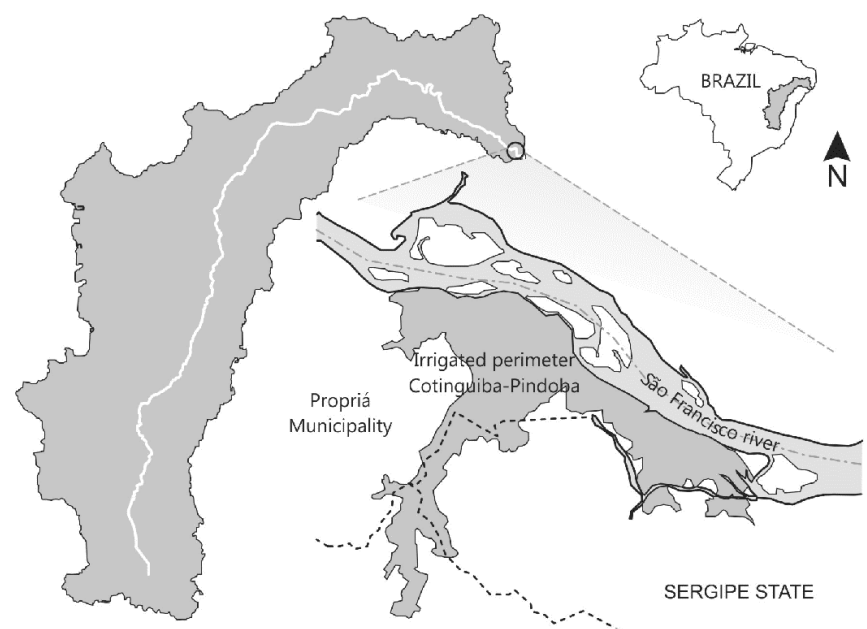

Figure 1. Location of Cotinguiba-Pindoba Irrigated Perimeter on lower São Francisco River 
the appropriate data related to the river stretch. The annual mean rainfall is $803.5 \mathrm{~mm}$, and a sharp change occurs in the rainfall distribution during the rainy period established between the months of March to August and during the dry period between the months of September to February.

The dominant soil class of the riverbank as well as throughout the sedimentary section is Fluvic Neosol with a composite particle size comprising over $90 \%$ medium, fine, and very fine sand. Soils with this characteristic typically have extremely low values of cohesion and shear strength. The original vegetation of the area consists of Atlantic rain forest bioma and reef patches along the coastal region, but these ecosystems are seriously threatened by deforestation being carried out for the purpose of cattle ranching or for irrigated agriculture.

The river bank of the studied sections has as its main features a sharp retreat of the bank line, granulometric composition with a predominance of medium and fine sand fractions, high friability, and proximity to the thalweg of the river (Figure 2).

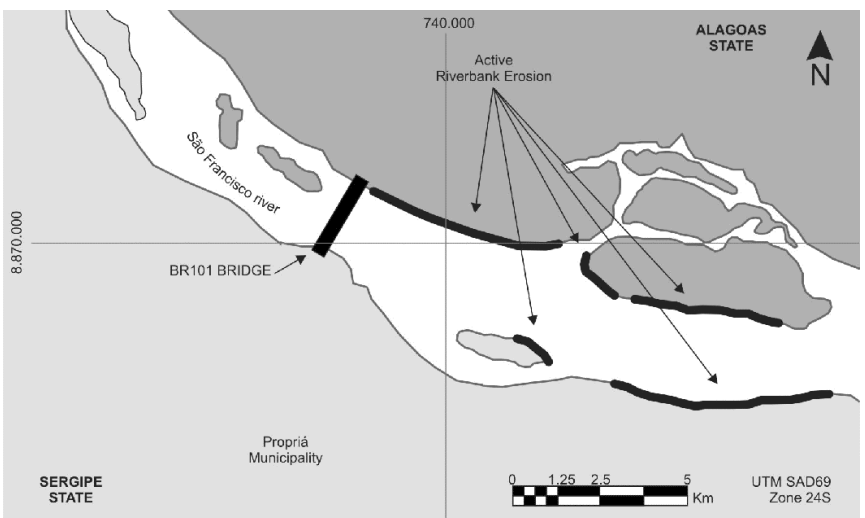

Figure 2. Physiognomy of the studied bank; the segments in the erosion process are shaded

In the study area (geographic Universal Transverse Mercator (UTM) coordinates: 8868.461,918 N/744.301,092 E, SAD69 Zone 24S), a large concentration of erosion occurrences have been previously identified on the almost completely deforested banks, specifically on a slope with approximate dimensions of $127 \mathrm{~m}$ length, $11 \mathrm{~m}$ width, and mean slope of $43.03 \%$; the area and perimeter were approximately $1.397 \mathrm{~m}^{2}$ and $276 \mathrm{~m}$, respectively (Holanda et al., 2008).

\section{Variables of erosion process}

To examine the influences of the variables on the erosion process, we collected and compared monthly erosion rates by the years 1999 and 2004 along the Lower São Francisco River obtained with the observations in this work using the pins method described by Hudson (1993).

In this work, three sections along the Cotinguiba-Pindoba irrigated perimeter of the Lower São Francisco River were defined. In each section, pins $1.0 \mathrm{~m}$ long and $0.006 \mathrm{~m}$ in diameter were installed, arranged in a regulated grid spacing of $3.0 \mathrm{~m}$ horizontally, and varying vertically according to the riverbank layer limits in each monitored section. The specification of the installed pins is in accordance with Fernandez (1990), who adapted the pin method for studying erosive processes along tropical rivers. The pins were painted with red lead paint to protect against rust and then with a light color to disguise them on the riverbank in order to avoid anthropic interferences or pin removals. The pins were identified and marked every $0.05 \mathrm{~m}$ to facilitate the measurements on the riverbank. It was performed 34 data collections during the year varying from 7 to 15 days between them.

The calculated average erosion rate was the result of the riverbank retreat sum divided by the sum of installed pins. In this way, the annual average erosion rate was the arithmetic mean of those measurements.

\section{Hydrological variables}

The data obtained from daily means were used in order to get the monthly means of each year and subsequently the monthly means for the analyzed period. It was considered the historical records for quota and discharge in the case of the conventional fluviometric station in the Municiplity of Propriá (49705000), (UTM coordinates: 8.870.010,209 N / 738.236,275 E, SAD69 Zone 24S). Propriá is distanced approximately 12 $\mathrm{km}$ far from the investigated stretch; the quota data, which was obtained from 1912 to 2007, was related to the Topographic Level Reference by IBGE (Instituto Brasileiro de Geografia e Estatísticas) code 2541U located on the right shoulder of the BR101 bridge, that connects the municipality of Propriá, located in Sergipe state, to the municipality of Porto Real do Colégio, located in Alagoas state. The mean flow velocity data were obtained from the relationship between the measured river discharge and sectional area in accordance with the equation $\mathrm{V}=\mathrm{Q} \mathrm{A}{ }^{-1}$, where $\mathrm{V}$ is the mean flow velocity $\left(\mathrm{m} \mathrm{s}^{-1}\right)$, $\mathrm{Q}$ is the measured discharge $\left(\mathrm{m}^{3} \mathrm{~s}^{-1}\right)$ and $\mathrm{A}$ is the measured sectional area $\left(\mathrm{m}^{2}\right)$ (Santos et al., 2001). The sectional area is not constant because of changes in the river channel, and hence, it became necessary to employ the historical records of cross-sectional profiles of the same station for the same period.

\section{Meteorological variables}

Among these variables, the annual mean rainfall and the velocity and direction of the prevailing winds are important. The historical rainfall records were obtained from the conventional pluviometric station at Propriá (01036048) (UTM coordinates: 8.869.978,450 N / 738.388,286 E, SAD69 Zone 24S) managed by the Agência Nacional de Águas (ANA) and operated by Companhia de Pesquisa de Recursos Minerais (CPRM) from 1912-2008.

The records of daily data on the prevailing wind direction and velocity were obtained for the period 1998-2007 from the meteorological station located at Propriá (83097), for the synoptic hours of 00 and $12 \mathrm{TMG}$; they were provided by the Instituto Nacional de Meteorologia (INMET). The data were tabulated using Microsoft Excel 2007 and processed using WRPLOT View 5.9 software; from the data, it became possible to draw the daytime and nighttime graphics by referring to the wind compass for the dry and rainy seasons.

\section{RESULTS AND DiscUSSION}

\section{Rainfall}

The annual mean rainfall recorded data ranged between 309.2 and $1.407,0 \mathrm{~mm}$ year $^{-1}$ (1972 and 1914, respectively). 
The highest values of the annual mean rainfall in the São Francisco River basin were found in the upper and Lower São Francisco River stretches (Silva \& Clarke, 2004; Pereira et al., 2007). However, if the influences on the hydraulic flow table are neglected, the rainfall that occurs in the lower course hardly contributes to the erosion process of its banks. This is due to the high drainage capacity of the soil of the river margin of this stretch; the soil texture (more than $90 \%$ sand) allows easy water infiltration without causing surface erosion, even during intense precipitation.

According to Pereira et al. (2007) the rainfall in the river basin regarding to the upper and middle course (up to the Itaparica's dam) contribute to the effective and cumulative increase of the river flow in its lower stretch (Figure 3), meaning that the river discharge downstream Itaparica's dam is one of the responsible components to erosion in the lower riverbanks.

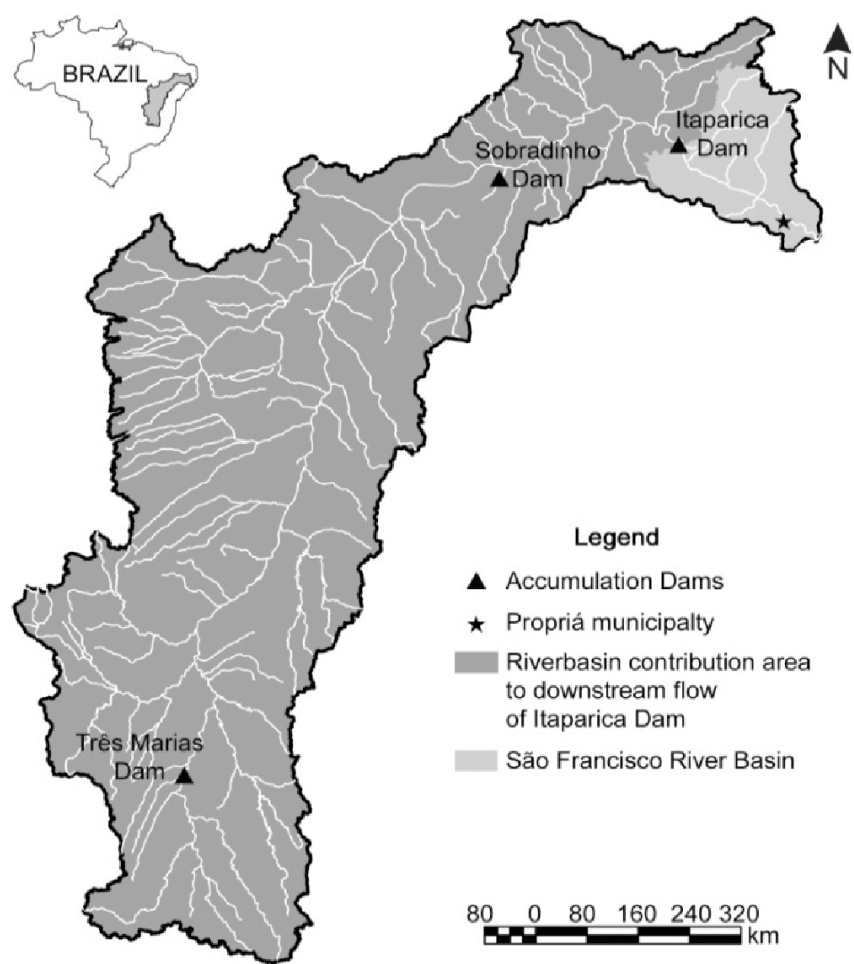

Figure 3. Contribution of the entire river basin to the flow upstream Itaparica dam

Out of nine majors dams for electric power generation in the basin, three are used for water accumulation (Três Marias, Sobradinho, and Itaparica); therefore, the rainfall that occurs in this drainage area controls the regulatory mechanisms of its defluent discharges in such a manner that when the water storage limit of the constructed dams and reservoirs exceeds the river water levels, there is a corresponding increase in the river discharge and flow velocity downstream. Such increase promotes hydrological and geomorphological changes in the entire hydrosystem toward the river mouth, and in particular, accelerates the bank erosion along the lower stretch. Furthermore, several authors (Shields Júnior et al., 2000; Nilsson \& Berggren, 2000; Graf, 2001; 2006; Wang et al., 2007) state that, in most cases, there is also a significant decline in the diversity of plant species and ichthyofauna downstream of these reservoirs. On the other hand, Pizzuto \& O'Neal (2009) report that the bank erosion rates due to dam deactivation can also increase.

By comparing the bank erosion rates along the Lower São Francisco River obtained by the years 1999 and 2004, the increase in erosion can be correlated with higher discharges along the river channel (Figure 4).

In December 1999, a remarkable increase in the erosion rate was noticed (Figure 4A); this was caused by a river discharge peak of $2.500 \mathrm{~m}^{3} \mathrm{~s}^{-1}$ that resulted from floods recorded at the beginning of the summer rainfall upstream. This erosion event can be attributed to the water discharge from the hydroelectric dams since December is characterized by the onset of the rainy season in the upper and middle river courses; during this period, the reservoirs have elevated water storage capacities.

Increased water levels in the river channel appear to threat the deforested banks with very low cohesion soils as the erosion intensifies. Only 4\% of the riverbanks of the São Francisco along its lower stretch shows remnants of the original riparian vegetation (Holanda et al., 2005).

Further, notable erosion rates also occurred from May to July 1999, characterized by a rainy season in Sergipe state but a dry season at the headwaters of the river. In this period, $89 \%$ of the observed river discharge were below the average regulated river discharge of $1.873,27 \mathrm{~m}^{3} \mathrm{~s}^{-1}$. Since the water quota and water discharge are proportional, bank erosion increases due to the frequency of the water depth becoming less than the usual and promoting the undercutting of the bank at soil layers with considerably less resistance; this is in agreement with Holanda et al. (2008). Note that Ray \& Sarma (2011) investigated the downstream of an electric power generation dam in India and found a direct relationship between the peak hours of power generation and increase in the erosion rates.

The highest erosion rates in 2004 (Figure 4B) were expected to correspond to the month of February when the river water velocity and discharge observed at the fluviometric station of Propriá were $2.52 \mathrm{~m} \mathrm{~s}^{-1}$ and $11.917 \mathrm{~m}^{3} \mathrm{~s}^{-1}$, respectively; during this period, the water spread over the lower and middle terraces as well as the floodplain, leading to significant destruction of the cultivated riverine areas. Moreover, this event caused changes in the morphology of unprotected banks, leading to the formation of new terraces; this demonstrates the changes in the river discharges during the monitored period. However, the erosion rates were higher only in the months of March and April, probably due to the occupation of the floodplain by the floods that occurred in February; Parker et al. (2008) explains this by suggesting that the already weak cohesive forces between the soil particles from the banks were further reduced by the lubricant effects of the water between the particles. In addition, as the water level decreases, the friction provided by the water flow in contact with the unprotected bank allows higher removal of soil particles.

The erosion and depositional sites are active along the left and right banks of the river and controlled by the floods that occur cyclically; as a result, the proximity of the thalweg to the banks during the hydrodynamic cycle is also altered. Hence, in an attempt to achieve a new morphological balance, another erosion cycle begins with the verticalization of the 
A.

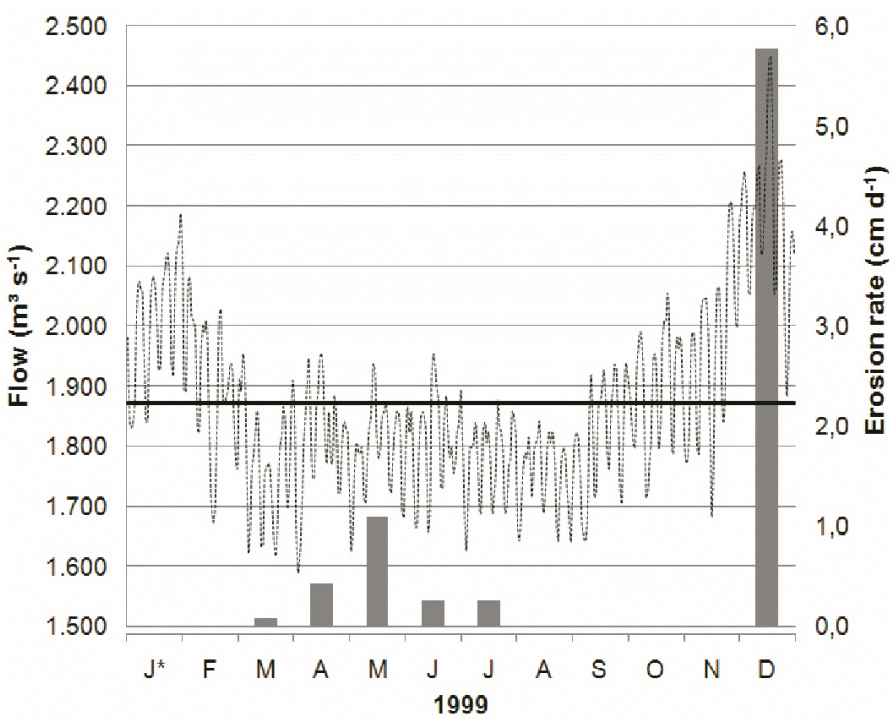

Figure 4. Monthly bank erosion rates along the Lower São Francisco River of the years 1999 and 2004 riverbanks leading to significant erosion rates in the period of july to september, but at levels well below the previous period; nevertheless, river discharges in a regulated pattern are driven by the operation of the dams for power generation.

River water velocity depends on the discharge behavior and had a minimum and a maximum of 153 and $1.74 \mathrm{~m} \mathrm{~s}^{-1}$, respectively, in 1999, and minimum and maximum of 86 and $252 \mathrm{~m} \mathrm{~s}^{-1}$, respectively, in 2004 (Figure 5).

The velocity curve for steep slopes shows that the water flow has a large kinetic energy that can be understood to represent the sheer power of the river flow. When transferred to the banks, this energy promotes the breaking of the bonding forces between the aggregation of the soil particles. Rosgen (1994) described a similar situation and identified the relationship between the flow velocity and its power to break the soil aggregation. In the case of the Lower São Francisco River, the situation is aggravated by the soil particle size of the bank with higher sandy material.

\section{Wind velocity and direction}

Wind velocity and direction are particularly influenced by the rainfall in the region. Such interactions in the Lower São Francisco River led to the predominance of winds of eastern

A.

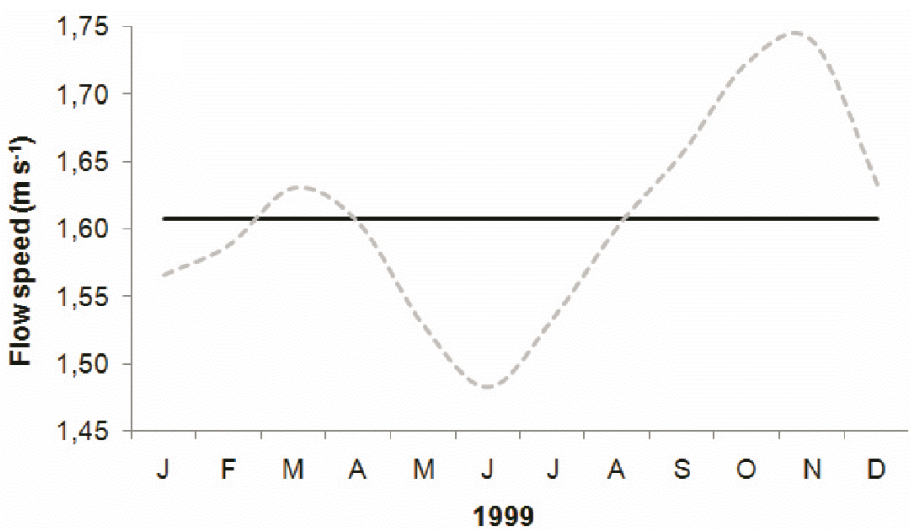

origin during the dry periods and winds of southeastern origin during the rainy season (Figure 6). Melo Júnior et al. (2006) have identified similar relationships between the frequency distribution of rainfall and prevailing wind directions.

Slight changes in the winds behavior as a function of the period of the day are also observed. The daytime winds have a higher mean velocity than the nighttime winds due to fast heating of the land surface during the daytime, which causes fast changes in the pressure gradient due to changes in the air density. At night, since the cooling of the land surface is slow, changes in the pressure gradient occur slowly, leading to lower wind velocities (Tubelis \& Nascimento, 1984; Pereira et al., 2003). Similar results were also obtained by Munhoz \& Garcia (2008), who observed that the daytime winds surpassed the nighttime winds during the warmer months, whereas the difference was reduced during the colder months. However, the daytime wind velocity was higher than the nighttime one. Nevertheless, it is known that the velocity and wind direction associated with wind fetch and the friction with the water surface are the major factors influencing the formation of natural waves in any stream. The impact of waves on the riverbank is a relevant component in the erosion processes in the Lower São

B.

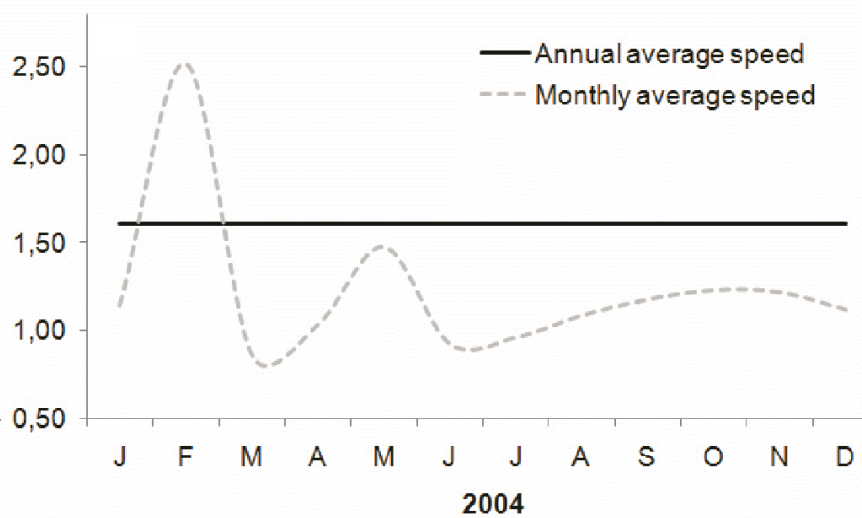

Figure 5. Daily velocity and annual mean flow at the fluviometric station, Propriá. (A) 1999, (B) 2004 

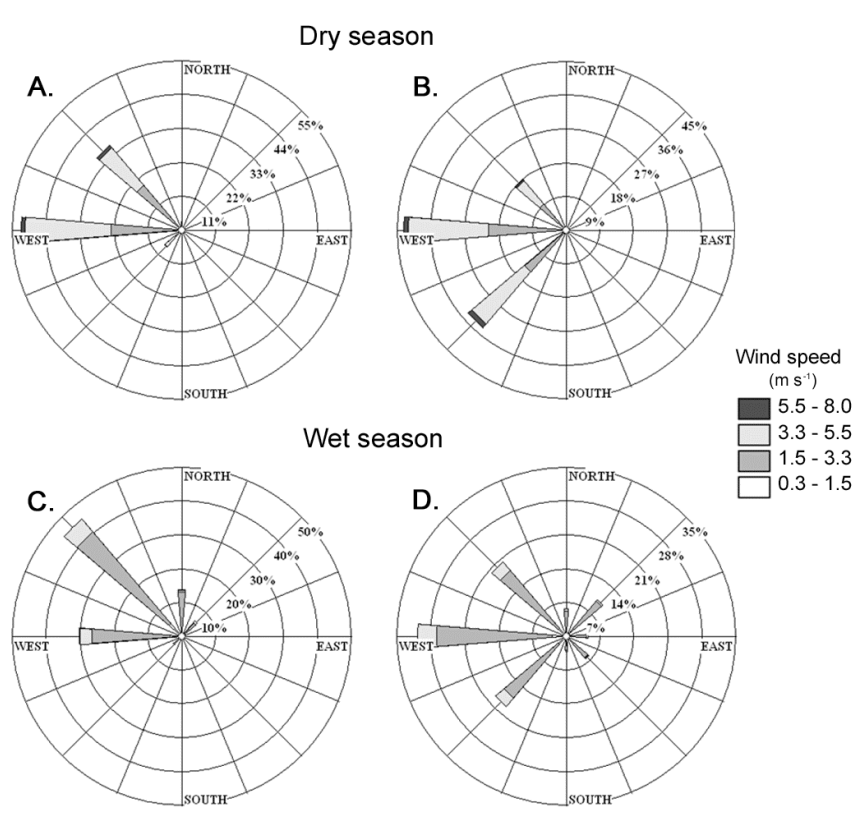

Figure 6. Daytime and nighttime wind compass (" $\mathrm{A}$ " and " $\mathrm{C}$ " and " $\mathrm{B}$ " and " $\mathrm{D}$ ", respectively), in the Lower São Francisco region recorded at the meteorological station in Propriá (83097) during the period 1998-2007

Francisco River, especially when the angle of wave incidence is parallel to the shore. Specifically in this river stretch, a specific form of joint action between waves and river current, occurs, and this interaction results in a bank morphology characterized by a concave curve wherein the highest retreat rates occur.

Thus, this study suggests that the wave fronts arise from the east because the resultant vector indicates the predominance of winds from that direction (40\%) and redirected to the south or southwest due to the resistance of the river flow (Figure 7). A similar situation was described by Williams (1952), when in specific season the winds provide energy from the waves that hit the unprotected riverbanks. Our observations suggest that the natural waves are responsible for eliminating large volumes of the eroded soil, resulting in changes in the river geomorphological pattern, promotion of the deposition of sediments in its bed and formation of increasing zones as small islands and sandbars.

The erosive effects from the more intense flows of the thalweg are greater when it is closer to the bank; this is the zone of greatest turbulence having higher flow velocities and accumulation of greater energies that promote landslide. However, the incidence angle of the water flow at the bank has temporal and spatial variations due to the characteristic meandering pattern of the Lower São Francisco River, and at undetermined timescales, the erosion processes migrate from one place to another and fluctuate in magnitude. Leinz \& Amaral (1978) report this in their works and state that large landslides are generated when the river flow is positioned parallel to the banks, promoting a fast retreat of the bank line.

An important consequence of this event is that it becomes possible to list the fast and progressive losses of soil from the riverbanks in Sergipe, the continuous formation of sandbars, and the increased water turbidity near the shore. From the geomorphological viewpoint, the effects of the investigated

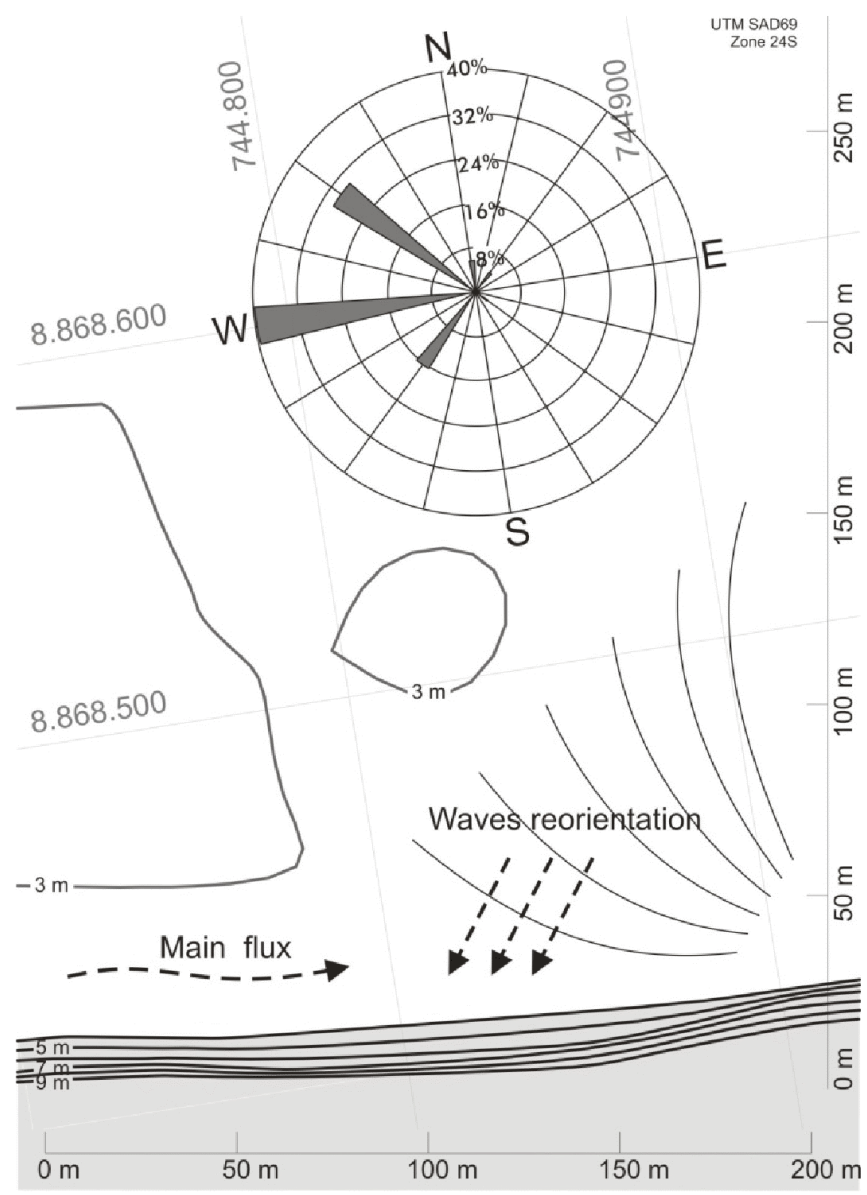

Figure 7. Topo/bathymetry grid of the study area showing the wind compass of prevailing winds and reorientation of the wave front

variables can be viewed as an adjustment to the channel morphology, which demonstrate the dynamics of the stream. Further, this river stretch has a wide width and low depth, i.e., exhibits characteristic behavior of lower courses and the energy from the current is concentrated in a narrow band of marginal quota, then the soil disaggregation from the bank is promoted. These results agree with those of Jiongxin (2008) who correlated the riverbed composition with the amount of energy employed by the channel flow.

\section{CONCLUSions}

1. Rainfall in Lower São Francisco river does not appear to directly contribute to the erosion processes on the investigated banks. On the other hand, the rainfall upstream Itaparica dam seems to strongly influences this process.

2. There is an interaction between the occurrences of winds and rainfall in the study area prevailing winds of eastern origin blow during the dry period while winds of southeastern origin blow during the rainy season, suggesting that these waves have strong influence at riverbank erosion process.

3 . The wave fronts originate from the eastern direction are redirected toward the south or southwest when they hit against the right margin banks, where higher erosion rates have occurred. 
4. Furthermore, the erosion process is more intensive in places where the thalweg is near the riverbank.

\section{ACKNOWLEDGEMENTS}

The authors thanks to the Conselho Nacional de Desenvolvimento Científico e Tecnológico (CNPq) on financial support for the development of this research.

\section{Literature Cited}

Bhattacharyya, K. The lower damodar river, India: Understanding the Human Role in Changing Fluvial Environment. London: Springer, 2011.308p.

Brandt, S. A. Classification of geomorphological effects downstream of dams. Catena, v.40, p.375-401, 2000.

Brighetti, G.; Martins, J. R. S. Estabilização e proteção de margens - PHD 5023 - Obras hidráulicas. São Paulo: Escola Politécnica/Departamento de Engenharia Hidráulica e Sanitária, 2001. 77p.

Casado, A. P. B; Holanda, F. S. R.; Araujo-Filho, F. A. G.; Yaguiu, P.; Bank erosion evolution in São Francisco River. Brazilian Journal of Soil Science, v.26, p.231-239, 2002.

Christofoletti, A. Geomorfologia fluvial. 2.ed. São Paulo: Edgard Blücher, 1981. 313p.

Christofoletti, A. Modelagem de sistemas ambientais. 1.ed. São Paulo: Edgard Blücher, 1999. 236p.

Coelho, A. L. N. Geomorfologia fluvial de rios impactados por barragens. Caminhos de Geografia, v.9, p.16-32, 2008.

Coops, H.; Geilen, N.; Verheij, H. J.; Boeters, R.; van der Velde, G. Interactions between waves, bank erosion and emergent vegetation: An experimental wave tank. Aquatic Botany, v.53, p.187-198, 1996.

Ellis J. T.; Sherman, D. J.; Bauer B. O.; Hart, J. Assessing the impact of an organic restoration structure on boat wake energy. Journal of Coastal Research, v.36, p.256-265, 2002.

Fernandez, O. V. Q. Mudanças no canal fluvial do Rio Paraná e processos de erosão nas margens: Região de Porto Rico-PR. São Paulo: IGCE/UNESP, 1990. 96p. Master Dissertation

Fernandez, O. V. Q.; Souza Filho, E. E. Efeitos do regime hidrológico sobre a evolução de um conjunto de ilhas no Rio Paraná, PR. Boletim Paranaense de Geociências, v.43, p.161-171, 1995.

Graf, W. L. Damage control: Dams and the physical integrity of America's rivers. Annals of the Association of American Geographers, v.91, p.1-27, 2001.

Graf, W. L. Downstream hydrologic and geomorphic effects of large dams on american rivers. Geomorphology, v.79, p.336-360, 2006.

Holanda, F. S. R.; Rocha, I. P.; Oliveira, V. S. Estabilização de taludes marginais com técnicas de bioengenharia de solos no Baixo São Francisco. Revista Brasileira de Engenharia Agrícola e Ambiental, v.12, p.570-575, 2008.

Holanda, F. S. R.; Santos, C. M.; Casado, A. P. B.; Bandeira, A. A.; Oliveira, V. S.; Fontes, L. C. S.; Rocha, I. P.; Araújo Filho, R. N.; Góis, S. S.; Vieira, T. R. Análise multitemporal e caracterização dos processos erosivos no Baixo São Francisco. Revista Brasileira de Geomorfologia, v.8, p.85-94, 2007.
Holanda, F. S. R.; Santos, L. G. C.; Santos, C. M. S.; Casado, A. P. B.; Pedrotti, A. Riparian fragments affected by bank erosion in the Lower São Francisco river, Northeastern Brazil. Journal of Brazilian Forest Science, v.29, p.148$152,2005$.

Hooke, J. M. An analysis of the processes of river bank erosion. Journal of Hydrology, v.42, p.39-62, 1979.

Houser, C. Relative importance of vessel-generated and wind waves to salt marsh erosion in a restricted fetch environment. Journal of Coastal Research, v.262, p.230-240, 2010.

Hudson, N. W. Field measurement of soil erosion and runoff. Rome: FAO, 1993. 140p.

Hughes, Z. J.; Fitzgerald, D. M.; Howes, N. C.; Rosen, P. S. Impact of natural waves and ferry wakes on bluff erosion and beach morphology in Boston harbor, USA. Journal of Coastal Research, v.50, p.497-501, 2007.

Jiongxin, X. Comparison of flow shear stress and energy expenditure between sand- and gravel-bed rivers and some geomorphological implications. Chinese Science Bulletin v.4, p.1224-1228, 2008.

Leinz, V.; Amaral, S. E. Geologia geral. São Paulo: Companhia Editora Nacional, 1978. 397p.

Manyari, W. V.; Carvalho Júnior, A. O. Environmental considerations in energy planning for the Amazon region: Downstream effects of dams. Energy Policy, v.35, p.65266534, 2007.

Melo Júnior, J. C. F.; Sediyama, G. C.; Ferreira, P. A.; Leal, B G.; Minusi, R. Distribuição espacial da frequência de chuvas na região hidrográfica do Atlântico, leste de Minas Gerais. Revista Brasileira de Engenharia Agrícola e Ambiental, v.10, p.417-425, 2006.

Munhoz , F. C.; Garcia, A. Caracterização da velocidade e direção predominante dos ventos para a localidade de Ituverava-SP. Revista Brasileira de Meteorologia, v.23, p.30-34, 2008.

Michalková, M.; Piégay, H.; Kondolf, G. M.; Greco, S. E. Lateral erosion of the Sacramento river, California (19421999), and responses of channel and floodplain lake to human influences. Earth Surface Processes and Landforms, v.36, p.257-272, 2011.

Nanson, G. C.; Krusentierna, A. von; Bryant, E. A.; Renilson, M. R. Experimental measurements of river-bank erosion caused by boat generated waves on the Gordon river, Tasmania. Regulated Rivers: Research and Management, v.9, p.1-14, 1994.

Nilsson, C.; Berggren, K. Alterations of riparian ecosystems caused by river regulation. Bioscience, v.50, p.783-792, 2000.

Parker, C; Simon, A; Thorne, C. R. The effects of variability in bank material on riverbank stability: Goodwin Creek, Mississippi. Geomorphology, v.101, p.533-543, 2008.

Pereira, S. B.; Pruski, F. F.; Novaes, F. L.; Silva, D. D.; Ramos, M. M. Distribuição espacial das variáveis hidrológicas na bacia do rio São Francisco. Engenharia na Agricultura, v.11, p.32-42, 2003.

Pereira, S. B.; Pruski, F.; Silva, D. D.; Ramos, M. M. Estudo do comportamento hidrológico do rio São Francisco e seus principais afluentes. Revista Brasileira de Engenharia Agrícola e Ambiental, v.11, p.615-622. 2007. 
Petts, G. E. Morphological changes of river channels consequent upon headwater impoundment. Journal of the Institution of Water Engineers and Scientists, v.34, p.374-382, 1980.

Pizzuto, J.; O’Neal, M. Increased mid-twentieth century riverbank erosion rates related to the demise of mill dams, South River, Virginia. Geology, v.37, p.19-22, 2009.

Posner, A. J.; Duan, J. G. Simulating river meandering processes using stochastic bank erosion coefficient. Journal of Geomorphology, v.163-164, p.26-36, 2011.

Ray, M. R.; Sarma, A. K. Minimizing diurnal variation of downstream flow in hydroelectric projects to reduce environmental impact. Journal of Hydro-Environment Research, v.5, p.177-185, 2011.

Rocha, P. C.; Souza Filho, E. E.; Fernandez, O. V. Q. Intensity of erosive processes at channel banks of up Parana river, Porto Rico Town area, Parana State, Brazil. In: International Symposium on Paleohydrology Geomorphology of Large Rivers and Field Conference Araguaia, 1999, Goiânia. Proceedings... Goiânia: GLOCOPGH/INQUA/IAG, 1999. p.56-59.

Rosgen, D. L. A classification of natural rivers. Catena, v.22, p.169-199, 1994.

Santos, I.; Fill, H. D.; Gugai, M. R. V. B.; Buba, H.; Kishi, R. T.; Marone, E.; Lautert, L. F. Hidrometria aplicada. Curitiba: Instituto de Tecnologia para o Desenvolvimento, 2001. 372p.
Shields Júnior, F. D.; Simon, A.; Steffen, L. J. Reservoir effects on downstream river channel migration. Environmental Conservation, v.27, p.54-66, 2000.

Silva, B. C.; Clarke, R. T. Análise estatística de chuvas intensas na Bacia do Rio São Francisco. Revista Brasileira de Meteorologia, v.19, p.265-272, 2004.

Simons, D. B.; Li, R. M. Engineering analysis of fluvial systems. Fort Collins: Simons, Li and Associates, 1982. 1300p.

Takken, I.; Govers, G.; Ciesiolka, C. A. A., Silburn, D. M.; Loch, R. J. Factors influencing the velocity-discharge relationship in rills. IAHS Publication, v.249, p.63-69, 1998.

Thorne, C. R.; Tovey, N. K. Stability of composite river banks. Earth Surface Processes and Landforms, v.6, p.469-484, 1981.

Tubelis, A.; Nascimento, F. C. L. Meteorologia descritiva Fundamentos e aplicações brasileiras. São Paulo: Nobel, 1984. 374p.

Tucci, C. E. M. Modelos hidrológicos. Porto Alegre: UFRGS: 2000. 678p.

Wang, Z.; Wu, B.; Wang, G. Fluvial processes and morphological response in the Yellow and Weihe rivers to closure and operation of Sanmenxia dam. Geomorphology, v.91, p.6579, 2007.

Williams, J. R. Effect of wind-generated waves on migration of the Yukon river in the Yukon flats, Alaska. Science, v.115, p.519-520, 1952. 